\title{
PENGARUH LIKUIDITAS DAN PERPUTARAN MODAL KERJA TERHADAP PROFITABILITAS PADA PT. INTAN KOMUNIKASI INDONESIA DI TANGERANG
}

\author{
1*Widya Intan Sari, ${ }^{2}$ Noryani, ${ }^{3}$ Asep Muhammad Lutfi \\ Universitas Pamulang, Tangerang Selatan, Banten, Indonesia \\ *dosen02451@unpam.ac.id
}

\begin{abstract}
Abstrak
Penelitian ini bertujuan untuk mengetahui pengaruh liquiditas dan perputaran modal kerja terhadap profitabilitas pada PT. Intan Komunikasi Indonesia di Tangerang. Metode yang digunakan adalah explanatory research dengan teknik analisis menggunakan analisis statistik dengan pengujian regresi, korelasi, determinasi dan uji hipotesis.Hasil penelitian ini Current Ratio berpengaruh signifikan terhadap Return on Asset sebesar 32,6\%, uji hipotesis diperoleh $\mathrm{t}$ hitung $>\mathrm{t}$ tabel atau $(4,055>1,691)$. Net Working Capital berpengaruh signifikan terhadap Return on Asset sebesar 29,6\%, uji hipotesis diperoleh t hitung $>t$ tabel atau $(3,780>1,691)$. Current Ratio dan Net Working Capital secara simultan berpengaruh signifikan terhadap Return on Asset dengan persamaan regresi $Y=9,045+0,740 \mathrm{X} 1+0,446 \mathrm{X} 2$ dan kontribusi pengaruh sebesar 42,9\%, uji hipotesis diperoleh $F$ hitung $>\mathrm{F}$ tabel atau $(15,958>2,890)$.
\end{abstract}

Kata Kunci: Liquiditas, Perputaran Modal Kerja, Profitabilitas.

\begin{abstract}
This study aims to determine the effect of liquidity and working capital turnover on profitability at PT. Indonesian Communication Diamond in Tangerang. The method used is explanatory research with analytical techniques using statistical analysis with regression testing, correlation, determination and hypothesis testing. The results of this study Current Ratio has a significant effect on Return on Assets of 32.6\%, hypothesis testing is obtained t count $>t$ table or ( $4.055>$ 1.691). Net Working Capital has a significant effect on Return on Assets of 29.6\%, hypothesis testing is obtained t count $>t$ table or $(3.780>1.691)$. Current Ratio and Net Working Capital simultaneously have a significant effect on Return on Assets with the regression equation $Y=$ $9.045+0.740 X 1+0.446 X 2$ and the contribution of the influence is $42.9 \%$, hypothesis testing is obtained F count $>$ F table or $(15.958>2.890)$.
\end{abstract}

Keywords: Liquidity, Working Capital Turnover, Profitability.

\section{PENDAHULUAN}

Persaingan usaha dalam industri saat ini demikian ketat, tak terkecuali dalam industri komunikasi. Berbagai perusahaan menawarkan berbagai kemudahan untuk menggunakan produk yang dihasilkan oleh suatu perusahaan tertentu, kondisi memicu persaingan antar perusahaan dalam industri. Salah satu program penjualan yang disampaikan oleh beberapa produk adalah cara pembayaran (term of payment) guna memiliki produk tertentu, tak terkecuali produk yang dihasilkan oleh PT. Intan Komunikasi Indonesia. Cara pembayaran yang ditawarkan adalah dengan cara mengangsur produk tertentu, tanpa bunga guna semata-mata untuk meningkatkan volume penjualan.

Konsekuensi logis dari penjualan kredit adalah bertambahnya piutang dagang yang pada giliranya mengganggu likuiditas perusahaan, terganggunya likuiditas ini, akan berpengaruh terhadap pemenuhan kewajiban baik kewajiban kepada pihak internal maupun kewajiban kepada pihak eksternal. Hal ini tentu saja berkaitan dengan aktivitas yang dilaksanakan oleh perusahaan yang membutuhkan likuiditas baik untuk kegiatan operasional/produksi maupun pembiayaan investasi (capital expenditure).

Kecukupan likuiditas menjadi hal penting sebagai penopang program peningkatan volume penjualan. Peningkatan volume penjualan akan memperbaiki banyak hal, namun tidak terbatas pada perbaikan kualitas maupun volume produksi, peningkatan pangsa pasar, kepercayaan konsumen maupun kreditur, yang pada gilirannya memperbaiki kinerja tak terkecuali profitabilitas.

Demikian halnya dengan modal kerja yang dibutuhkan untuk memproduksi suatu barang atau jasa dibutuhkan kecukupan dana yang menjamin terselenggaranya proses 
produksi/jasa. Pada dasarnya modal kerja itu terdiri dari 2 (dua), yaitu pertama, bagian yang tetap atau bagian yang permanen yaitu jumlah minimum yang harus tersedia agar perusahaan dapat berjalan lancar tanpa kesulitan keuangan, dan kedua jumlah modal kerja yang variabel yang jumlahnya tergantung pada aktifitas musiman dan kebutuhan-kebutuhan di luar aktivitas biasa.

Idealnya modal cukup memenuhi kebutuhan produksi/operasi untuk jangka waktu tertentu sebagaimana dimaksud dalam Rencana Kerja dan Anggaran Perusahaan (RKAP), yang lazim digunakan. Menurut Dr. Kasmir (2014:304) Secara umum arti penting modal kerja bagi perusahaan, terutama bagi kesehatan keuangan perusahaan, yaitu sebagai berikut: 1) Kegiatan seorang manajer keuangan lebih banyak di habiskan di dalam kegiatan operasional perusahaan dari waktu ke waktu. 2) Investasi dalam aset lancar cepat dan sering sekali mengalami perubahan serta cenderung labil. Sedangkan aset lancar adalah modal kerja perusahaan artinya perubahan tersebut akan berpengaruh terhadap modal kerja. Oleh karena itu, perlu mendapat perhatian yang sungguh-sungguh dari manajer keuangan. 3) Dalam praktiknya sering kali bahwa separuh dari total asset merupakan bagian dari aset lancar, yang merupakan modal kerja perusahaan. 4) Bagi perusahaan yang relative kecil, relative terbatas untuk memasuki pasar dengan modal besar dan jangka panjang. Pendanaan perusahaan lebih mengandalkan pada utang jangka pendek, seperti utang dagang, utang bank satu tahun yang tentunya dapat mempengaruhi modal kerja. 5) Terdapat hubungan yang sangat erat antara pertumbuhan penjualan dengan kebutuhan modal kerja. Kenaikan penjualan berkaitan dengan piutang, persedian dan juga kas. Demikian pula sebaliknya apabila terjadi penurunan penjualan, akan berpengaruh terhadap komponen dalam aset lancar.

Memperhatikan hal sebagaimana tersebut, maka tujuan manajemen modal kerja: 1) Guna memenuhi kebutuhan likuiditas perusahaan, 2) Dengan modal kerja yang cukup perusahaan memiliki kemampuan untuk memenuhi kewajiban pada waktunya. 3) Memunginkan perusahaan untuk memperoleh tambahan dana dari pada kreditur apabila rasio keungan memenuhi syarat. 4) Memaksimalkan penggunaan aset lancar guna meningkatkan penjualan dan laba. 5) Melindungi diri apabila terjadi krisis modal kerja akibat turunnya nilai aset lancar.

Perputaran modal kerja dimulai dari saat kas diinvestasikan dalam komponen modal kerja sampai saat kembali menjadi kas. Semakin pendek periode perputaran modal kerja, semakin cepat perputaranya sehingga perputaran modal kerja semakin tinggi dan perusahaan semakin efisien yang pada akhirnya profitabilitas meningkat.

Demikian halnya bilamana perputaran modal kerja yang rendah menunjukan adanya kelebihan modal kerja yang mungkin disebabkan rendahnya perputaran persediaan, piutang atau adanya saldo kas yang terlalu besar. Demikian pula sebaliknya jika perputaran modal kerja yang tinggi, dimungkinkan tingginya perputaran persediaan, perputaran piutang atau saldo kas yang terlalu kecil.

Modal kerja dapat di artikan sebagai kelebihan aset lancar terhadap hutang jangka pendek. Kelebihan ini berasal dari hutang jangka panjang dan modal sendiri yang disebut dengan modal kerja bersih (net working capital). Kemampuan suatu perusahaan untuk membayar sedemikian besarnya sehingga mampu memenuhi segala kewajiban finansialnya yang harus segera dipenuhi, dapat dikatakan bahwa perusahaan tersebut disebut likuid dan sebaliknya jika perusahaan tersebut tidak memiliki kemampuan untuk membayar disebut ilikuid.

Bilamana dikaitkan dengan siklus operasi normal perusahaan yaitu mencakup siklus pembelian-penjualan-penagihan. Likuiditas merupakan salah satu faktor yang mementukan sukses atau gagalnya manajemen kuangan perusahaan. Jumlah alat pembayaran yang dimiliki perusahaan menjadi sumber kesedangan perusahaan dalam membayar kewajiban yang harus di bayarkan.

Makin tinggi likuiditas maka makin baiklah posisi perusahaan di mata kreditur, namun disisi lain terdapat beban kesempatan (opportunity cost) yang cukup material. Hal ini memberi arti, bila perusahaan memutuskan menetapkan modal kerja dalam jumlah yang besar, kemungkinan tingkat likuiditas akan terjaga namun kesempatan untuk memperoleh laba akan menurun yang 
pada akhirnya berdampak pada menurunya profitabilitas, sebaliknya jika perusahaan ingin memaksimalkan profitabilitas, kemungkinan dapat mempengaruhi tingkat likuiditas perusahaan.

Profitabilitas adalah hasil akhir dari sejumlah kebijakan dan keputusan yang dilakukan oleh perusahaan. Profitabilitas dapat memberikan petunjuk yang berguna dalam menilai keefektifan dari operasi sebuah perusahaan, sehingga rasio profitabilitas akan menunjuk kombinasi dari efek likuiditas, manajemen aset, dan utang pada hasil-hasil operasi. Profitabilitas akan menunjukan perimbangan pendapatan dan kemampuan perusahaan dalam menghasilkan laba pada berbagai tingkat operasi, sehingga rasio ini akan mencerminkan efektifitas dan keberhasilan manajemen secara keseluruhan.

Perusahaan retail dipilih karena memiliki potensi dalam mengembangkan produknya lebih cepat karna semua orang tentunya ingin berkomunikasi dengan baik menyampaikan informasi dan menerima informasi, walaupun sekarang teknologi lebih canggih tetapi tetap saja banyak konsumen yang tetap memilih HT (Handy Talkie) sebagai alat penyampai informasi tanpa pulsa dan dapat berkomunikasi lebih cepat dengan banyak orang.

Dengan terus meningkatnya permintaan konsumen terhadap alat komunikasi maka setiap perusahaan perlu memiliki kemampuan manajerial yang memadai, agar perusahaan yang dijalankan mampu bersaing dengan perusahaan dalam industri. Setiap perusahaan pasti memiliki strategi demi mingkatkan penjualannya, sehingga produk yang dijual mampu menarik minat konsumen guna meningkatkan penjualan produk, dengan meningkatnya penjualan produk yang dihasilkan, maka profitabilitas perusahaan juga akan meningkat. Dengan meningkatnya profitabilitas dapat mencerminkan keberhasilan menejemen dalam menjalankan suatu perusahaan.

Dengan memperhatikan fenomena bisnis retail khususnya Handy Talkie (HT), serta latar belakang Penulis yang telah mengelola bisnis ini, saya tertarik untuk memilih judul " Pengaruh Liquiditas Dan Perputaran Modal Kerja Terhadap
Profitabilitas Pada PT. Intan Komunikasi Indonesia di Tangerang".

\section{TINJAUAN PUSTAKA}

\section{Rasio Liquiditas}

Rasio Likuiditas yang terdiri Current Ratio, Quick Ratio dan Cash Ratio Alat ukur yang digunakan dalam penelitian ini yaitu Current Ratio dapat dirumuskan sebagai berikut:

$$
\text { Current Ratio }=\frac{\text { Aset Lancar }}{\text { Hutang Lancar }}
$$

(Sumber dari Agus Sartono 2015:116)

\section{Perputaran Modal Kerja}

Perputaran Modal Kerja Alat ukur yang digunakan dalam penelitian ini yaitu Perputaran Modal Kerja (Working Capital Turnover) dapat dirumuskan sebagai berikut:

$$
\begin{aligned}
& \text { Perputaran Modal Kerja } \\
& =\frac{\text { Penjualan Bersih }}{\text { Modal Kerja Rata }- \text { Rata }}
\end{aligned}
$$

(Sumber dari Kasmir 2015:183)

\section{Profitabilitas}

Pada penelitian ini yang menjadi variabel dependen adalah profitabilitas. Alat ukur dari profitabilitas adalah

$$
\begin{aligned}
& \text { ROA }=\frac{\text { Laba Bersih }}{\text { Total Aset }} \\
& \text { (Sumber dari Eugene F. Brigham } \\
& 2010: 148)
\end{aligned}
$$

\section{METODE}

Populasi dalam penelitian ini laporan keuangan PT. Intan Komunikasi Indonesia di Tangerang. Sampel dalam penelitian ini berjumlah laporan keuangan PT. Intan Komunikasi Indonesia di Tangerang. Jenis penelitian yang dipakai adalah kuantitatif, dimana tujuannya adalah untuk mengetahui pengaruh antara variabel bebas terhadap variabel terikat baik parsial maupun simultan. Dalam menganalisis data digunakan uji instrumen, uji asumsi klasik, regresi, koefisien korelasi, koefisien determinasi dan uji hipotesis.

\section{HASIL DAN PEMBAHASAN}

\section{Analisis Deskriptif}

Pada pengujian ini digunakan untuk mengetahui skor minimum dan maksimum, mean score dan standar 
deviasi dari masing-masing variabel. Adapun hasilnya sebagai berikut:

Tabel 1. Hasil Analisis Descriptive Statistics

Descriptive Statistics

\begin{tabular}{lr|r|r|r|r} 
& N & Minimum & Maximum & Mean & Std. Deviation \\
\hline Current Ratio (X1) & 36 & 34 & 45 & 39.54 & 3.108 \\
\hline Net Working Capital (X2) & 36 & 43 & 65 & 54.31 & 4.748 \\
\hline Return On Assets (Y) & 36 & 54 & 72 & 62.53 & 5.014 \\
\hline Valid N (listwise) & 36 & & & & \\
\hline
\end{tabular}

Current Ratio diperoleh persentase minimum sebesar $34,0 \%$ dan persentase maximum 45,0 dengan rata-rata sebesar $39,54 \%$ dengan standar deviasi 2,108.

Net Working Capital diperoleh persentase minimum sebesar $43,0 \%$ dan persentase maximum $65,0 \%$ dengan rata-rata sebesar $54,31 \%$ dengan standar deviasi 4,748.

Return on Asset diperoleh persentase minimum sebesar $54,0 \%$ dan persentase maximum 47 dengan rata-rata sebesar 62,53\% dengan standar deviasi 5,014.

\section{Analisis Kuantitatif}

Pada analisis ini dimaksudkan untuk mengetahui pengaruh variabel independen terhadap variabel dependen. Adapun hasil pengujian sebagai berikut:

\section{a. Analisis Regresi Linier Berganda}

Uji regresi ini dimaksudkan untuk mengetahui perubahan variabel dependen jika variabel independen mengalami perubahan. Adapun hasil pengujiannya sebagai berikut:

Tabel 2. Hasil Pengujian Regresi Linier Berganda

\section{Coefficients ${ }^{\mathrm{a}}$}

Unstandardized Coefficients Standardized Coefficients

\begin{tabular}{|c|c|c|c|c|c|}
\hline Model & B & Std. Error & Beta & $\mathrm{t}$ & Sig. \\
\hline 1 (Constant) & 9.045 & 9.494 & & .953 & .348 \\
\hline Current Ratio (X1) & .740 & 208 & .459 & 3.565 & .001 \\
\hline Net Working Capital (X2) & .446 & .136 & .422 & 3.279 & .002 \\
\hline
\end{tabular}

a. Dependent Variable: Return On Assets (Y)

Berdasarkan hasil pengujian pada tabel di atas, diperoleh persamaan regresi $Y=9,045+0,740 X 1+0,446 X 2$. Dari persamaan tersebut dijelaskan sebagai berikut:

1) Konstanta sebesar 9,045 diartikan jika Current Ratio dan Net Working Capital tidak ada, maka telah terdapat nilai Return on Asset sebesar 9,045 point.

2) Koefisien regresi Current Ratio sebesar 0,740, angka ini positif artinya setiap ada peningkatan Current Ratio sebesar 0,740 maka Return on Asset juga akan mengalami peningkatan sebesar 0,740 point.

Tabel 3. Hasil Pengujian Koefisien Korelasi Current Ratio Terhadap Return on Asset.

Correlations $^{\mathbf{b}}$

Current Ratio (X1) Return On Assets (Y)

\begin{tabular}{llrr}
\hline Current Ratio (X1) & Pearson Correlation & 1 & $.571^{* *}$ \\
\cline { 2 - 4 } & Sig. (2-tailed) & $.571^{* *}$ & .000 \\
\hline \multirow{2}{*}{ Return On Assets (Y) } & Pearson Correlation & .000 & 1 \\
\cline { 2 - 4 } & Sig. (2-tailed) & & \\
\hline \multirow{2}{*}{$* *$. Correlation is significant at the 0.01 level (2-tailed). } &
\end{tabular}


b. Listwise $\mathrm{N}=36$

Berdasarkan hasil pengujian diperoleh nilai korelasi sebesar 0,571 hubungan yang sedang terhadap artinya Current Ratio memiliki Return on Asset.

Tabel 4. Hasil Pengujian Koefisien Korelasi Net Working Capital Terhadap Return on Asset.

Correlations ${ }^{\mathbf{b}}$

\begin{tabular}{llr|r} 
& & Net Working Capital (X2) & Return On Assets (Y) \\
\hline Net Working Capital (X2) & Pearson Correlation & 1 & $.544^{* *}$ \\
\cline { 2 - 4 } & Sig. (2-tailed) & & .001 \\
\hline Return On Assets (Y) & Pearson Correlation & $.544^{* *}$ & 1 \\
\cline { 2 - 4 } & Sig. (2-tailed) & .001 & \\
\hline
\end{tabular}

**. Correlation is significant at the 0.01 level (2-tailed).

b. Listwise $\mathrm{N}=36$

Berdasarkan hasil pengujian diperoleh nilai korelasi sebesar 0,544 artinya Net Working Capital memiliki

hubungan yang sedang terhadap Return on Asset.

Tabel 5. Hasil Pengujian Koefisien Korelasi Current Ratio dan Net Working Capital secara simultan Terhadap Return on Asset.

Model Summary

\begin{tabular}{ll|l|l|l|} 
Model & R & R Square & Adjusted R Square & Std. Error of the Estimate \\
\hline 1 &
\end{tabular}

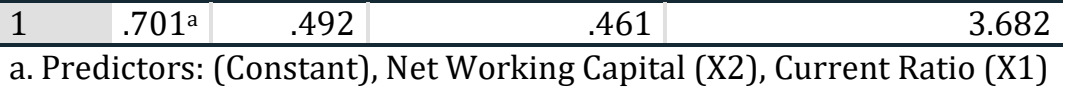

Berdasarkan hasil pengujian diperoleh nilai korelasi sebesar 0,701 artinya Current Ratio dan Net Working Capital secara simultan memiliki hubungan yang kuat terhadap Return on Asset.

\section{c. Analisis Koefisien Determinasi}

Analisis koefisien determinasi dimaksudkan untuk mengetahui besarnya persentase pengaruh dari variabel independen terhadap variabel dependen baik secara parsial maupun simultan. Adapun hasil pengujian sebagai berikut:

Tabel 6. Hasil Pengujian Koefisien Determinasi Current Ratio Terhadap Return on Asset.

Model Summary

\begin{tabular}{ll|l|l|l|} 
Model & R & R Square & Adjusted R Square & Std. Error of the Estimate \\
\hline 1 & &
\end{tabular}

\begin{tabular}{lrrrr}
\hline 1 & $.571^{\mathrm{a}}$ & .326 & .306 & 4.177 \\
\hline
\end{tabular}

a. Predictors: (Constant), Current Ratio (X1)

Berdasarkan hasil pengujian diperoleh nilai determinasi sebesar

kontribusi pengaruh sebesar 32,6\% terhadap Return on Asset. 0,326 artinya Current Ratio memiliki

Tabel 7. Hasil Pengujian Koefisien Determinasi Net Working Capital Terhadap Return on Asset.

Model Summary

\begin{tabular}{ll|l|l|l} 
Model & R & R Square & Adjusted R Square & Std. Error of the Estimate \\
\hline
\end{tabular}

\begin{tabular}{lrrrr}
\hline 1 & $.544^{\mathrm{a}}$ & .296 & .275 & 4.269 \\
\hline a. Predictors: (Constant), Net Working Capital (X2)
\end{tabular}

Berdasarkan hasil pengujian diperoleh nilai determinasi sebesar 0,296 artinya Net Working Capital memiliki kontribusi pengaruh sebesar 29,6\% terhadap Return on Asset. 
Tabel 8. Hasil Pengujian Koefisien Determinasi Current Ratio dan Net Working Capital Terhadap Return on Asset.

\section{Model Summary}

\begin{tabular}{ll|l|l|l} 
Model & R & R Square & Adjusted R Square & Std. Error of the Estimate \\
\hline
\end{tabular}

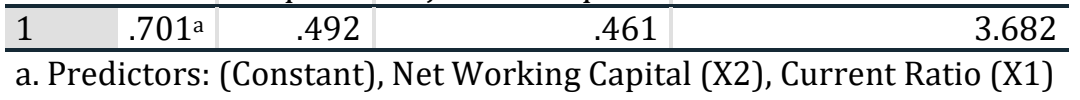

Berdasarkan hasil pengujian diperoleh nilai determinasi sebesar 0,492 artinya Current Ratio dan Net Working Capital secara simultan memiliki kontribusi pengaruh sebesar 42,9\% terhadap Return on Asset, sedangkan sisanya sebesar $57,1 \%$ dipengaruhi faktor lain.

\section{d. Uji Hipotesis}

Uji hipotesis Parsial (Uji t)

Pengujian hipotesis dengan uji $t$ digunakan untuk mengetahui hipotesis parsial mana yang diterima.

Hipotesis pertama: Terdapat pengaruh yang signifikan antara Current Ratio terhadap Return on Asset. Hipotesis kedua: Terdapat pengaruh yang signifikan antara Net Working Capital terhadap Return on Asset.

Tabel 9. Hasil Uji Hipotesis Current Ratio Terhadap Return on Asset.

\section{Coefficients $^{\mathrm{a}}$}

Unstandardized Coefficients Standardized Coefficients

\begin{tabular}{lr|r|r|c|c} 
Model & B & Std. Error & Beta & t & Sig. \\
\hline 1 (Constant) & 26.112 & 9.008 & & 2.899 & .007 \\
\hline Current Ratio (X1) & .921 & .227 & .571 & 4.055 & .000 \\
\hline
\end{tabular}

a. Dependent Variable: Return On Assets (Y)

Berdasarkan hasil pengujian pada tabel di atas, diperoleh nilai $\mathrm{t}$ hitung $>\mathrm{t}$ tabel atau $(4,055>1,691)$, dengan demikian hipotesis pertama

Tabel 10. Hasil Uji Hipotesis Net Working Capital Terhadap Return on Asset.

\section{Coefficients ${ }^{\mathrm{a}}$}

\begin{tabular}{l|r|r|r|r|r} 
& \multicolumn{2}{c}{ Unstandardized Coefficients } & Standardized Coefficients & B \\
Model & $\mathrm{B}$ & Std. Error & Beta & t & Sig. \\
\hline 1 (Constant) & 31.333 & 8.285 & & 3.782 & .001 \\
\hline Net Working Capital (X2) & .574 & .152 & .544 & 3.780 & .001 \\
\hline
\end{tabular}

yang diajukan bahwa terdapat pengaruh yang signifikan atara Current Ratio terhadap Return on Asset diterima.

a. Dependent Variable: Return On Assets (Y)

Berdasarkan hasil pengujian pada tabel di atas, diperoleh nilai $\mathrm{t}$ hitung $>t$ tabel atau $(3,780>1,691)$, dengan demikian hipotesis kedua yang diajukan bahwa terdapat pengaruh yang signifikan atara Net Working Capital terhadap Return on Asset diterima.

\section{Uji Hipotesis Simultan (Uji F)}

Pengujian hipotesis dengan uji $\mathrm{F}$ digunakan untuk mengetahui hipotesis simultan yang mana yang diterima.

Hipotesis ketiga Terdapat pengaruh yang signifikan antara Current Ratio dan Net Working Capital terhadap Return on Asset.

Tabel 12. Hasil Uji Hipotesis Current Ratio dan Net Working Capital Terhadap Return on

Asset.

ANOVA $^{\mathrm{a}}$

\begin{tabular}{|c|c|c|c|c|c|}
\hline Model & Sum of Squares & df & Mean Square & $\mathrm{F}$ & Sig. \\
\hline 1 Regression & 432.674 & 2 & 216.337 & 15.958 & $.000^{\mathrm{b}}$ \\
\hline Residual & 447.377 & 33 & 13.557 & & \\
\hline Total & 880.051 & 35 & & & \\
\hline
\end{tabular}

a. Dependent Variable: Return On Assets (Y) 
b. Predictors: (Constant), Net Working Capital (X2), Current Ratio (X1)

Berdasarkan hasil pengujian pada tabel di atas, diperoleh nilai $\mathrm{F}$ hitung $>\mathrm{F}$ tabel atau $(15,958>2,890)$, dengan demikian hipotesis ketiga yang diajukan bahwa terdapat pengaruh yang signifikan atara Current Ratio dan Net Working Capital terhadap Return on Asset diterima.

\section{Pembahasan Hasil Penelitian}

\section{Pengaruh Current Ratio Terhadap Return on Asset}

Current Ratio berpengaruh signifikan terhadap Return on Asset dengan korelasi sebesar 0,571 atau memiliki hubungan yang sedang dengan kontribusi pengaruh sebesar 32,6\%. Pengujian hipotesis diperoleh nilai $t$ hitung $>\mathrm{t}$ tabel atau $(4,055>1,691)$. Dengan demikian hipotesis pertama yang diajukan bahwa terdapat berpengaruh signifikan antara Current Ratio terhadap Return on Asset diterima.

\section{Pengaruh Net Working Capital Terhadap Return on Asset}

Net Working Capital berpengaruh signifikan terhadap Return on Asset dengan korelasi sebesar 0,544 atau memiliki hubungan yang sedang dengan kontribusi pengaruh sebesar 29,6\%. Pengujian hipotesis diperoleh nilai $t$ hitung $>\mathrm{t}$ tabel atau $(3,780>1,691)$. Dengan demikian hipotesis kedua yang diajukan bahwa terdapat berpengaruh signifikan antara Net Working Capital terhadap Return on Asset diterima.

\section{Pengaruh Current Ratio dan Net Working Capital Terhadap Return on Asset}

Current Ratio dan Net Working Capital berpengaruh signifikan terhadap Return on Asset dengan diperoleh persamaan regresi $\mathrm{Y}=9,045+0,740 \mathrm{X} 1+$ $0,446 \times 2$, nilai korelasi sebesar 0,701 atau memiliki hubungan yang kuat dengan kontribusi pengaruh sebesar 42,9\% sedangkan sisanya sebesar 57,1\% dipengaruhi faktor lain. Pengujian hipotesis diperoleh nilai $\mathrm{F}$ hitung $>\mathrm{F}$ tabel atau $(15,958>2,890)$. Dengan demikian hipotesis ketiga yang diajukan bahwa terdapat berpengaruh signifikan antara Current Ratio dan Net Working Capital terhadap Return on Asset diterima.

\section{PENUTUP}

\section{Simpulan}

1. Current Ratio berpengaruh signifikan terhadap Return on Asset dengan kontribusi pengaruh sebesar $32,6 \%$. Uji hipotesis diperoleh nilai $\mathrm{t}$ hitung $>\mathrm{t}$ tabel atau $(4,055>1,691)$.

2. Net Working Capital berpengaruh signifikan terhadap Return on Asset dengan kontribusi pengaruh sebesar 29,6\%. Uji hipotesis diperoleh nilai $t$ hitung $>\mathrm{t}$ tabel atau $(3,780>1,691)$.

3. Current Ratio dan Net Working Capital berpengaruh signifikan terhadap Return on Asset dengan kontribusi pengaruh sebesar $42,9 \%$ sedangkan sisanya sebesar $57,1 \%$ dipengaruhi faktor lain. Uji hipotesis diperoleh nilai $\mathrm{F}$ hitung $>\mathrm{F}$ tabel atau $(15,958>2,890)$.

\section{Saran}

Berdasarkan pembahasan dan kesimpulan penelitian ini serta hasil data yang telah diteliti, maka peneliti memberikan saran-saran sebagai berikut:

1. Kemampuan perusahaan dalam menghasilkan laba mengalami fluktuasi. Perusahaan harus lebih memperhatikan kemampuan perusahaan dalam menghasilkan laba dengan cara mengefektifitaskan penggunaan biaya, me-manage utang, mengatur penggunaan dana eksternal, dalam hal pembiayaan perusahaan tiap tahunnya, dan tetap mempertahankan modal kerja yang baik dan efisien sehingga para investor tertarik untuk menanamkan modalnya pada perusahaan.

2. Kefektifan penggunaan modal kerja perusahaan terkait dengan hasil penjualan mengalamu penurunan. Perusahaan harus lebih tepat dalam mengukur perputaran modal kerja dengan cara membandingkan antara penjualan dengan modal kerja dengan baik terutama penjualan yang akan di bandingkan adalah penjualan bersih (net sales) dalam suatu periode. 
3. Perusahaan harus dapat bertindak secara cermat dalam memilih dan mengambil keputusan terkait prosperk perusahaan. Dengan mengukur tingkat current ratio dan working capitan turnover dengan pencapaian laba yang maksimal sehingga nilai buku perusahaan semakin membaik

4. Bagi peneliti selanjutnya diharapkan untuk menambah faktor- 90anjan lain yang dapat mempengaruhi harga saham dan meneliti perusahaan jenis tertentu seperti perusahaan manufaktur, asuransi, perkebunan dan lain-lain atau dapat pula meneliti perusahaan secara heterogen. Hal ini bertujuan untuk mendapatkan hasil yang lebih sedang. Selain itu sebaiknya periode pengamatan untuk penelitian selanjutnya menggunkan periode pengamatan yang lebih panjang dari pengamatan penelitian ini, hal ini bertujuan untuk mempersedang hasil penelitian.

\section{DAFTAR PUSTAKA}

Agus Harjito \& Martono, (2010) "Manajemen Keuangan" Penerbit Ekonisia Yogyakarta.

Anjayani, N. S., Lutfi, A. M., Suhartono, A., Sari, W. I., \& Sunarsi, D. (2020). Pengaruh Perputaran Persediaan dan Rasio Perputaran Aktiva Terhadap Return on Invesment Pada PT Gudang Garam Tbk. TIN: Terapan Informatika Nusantara, 1(4), 171-176.

Ayu Sri Mahatma Dewi dan Ary Wirajaya (2013), Pengaruh Struktur Modal, Profitabilitas Dan Ukuran Perusahaan Terhadap Nilai Perusahan E-Jurnal Akuntansi Universitas Udayana 4.2: 358-372

Dewi Ernawati dan Dini Widyawati (2015), Pengaruh Profitabilitas, Leverage dan Ukuran Perusahaan terhadap Nilai Perusahaan. Jurnal Ilmu \& Riset Akuntansi Vol. 4 No. 4

Fahmi, irham (2012), "Pengantar Manajemen Keuangan" Cetakan pertama penerbit Alfabeta, Bandung.

Gunawan, Imam (2016), "Pengantar Statistika Inferensial” PT. Rajagrafindo Persada, Jakarta

Hanafi, Mamduh M. (2004), Manajemen Keuangan. Yogyakarta: BPFE

"Fakultas Ekonomi dan Bisnis, Jakarta
Kasmir (2008), “Analisis Laporan keuangan”, penerbit raja grafindo persada, Jakarta

Munawir (2010), "Analisis Laporan Keuangan”, Edisi Ke Empat, Penerbit Liberty, Yogyakarta.

Muslimat, A., Muhsin, H., Wahid, H. A., Yulistiana, I., Sunarsi, D., Dewi, K., ... \& Ilham, D. (2021). Develop Technology Based Multimedia For Indonesian Teachers. Journal of Contemporary Issues in Business and Government, 27(1), 1871-1882.

Purwanti, Y. (2021). The Influence Of Digital Marketing \& Innovasion On The School Performance. Turkish Journal of Computer and Mathematics Education (TURCOMAT), 12(7), 118-127.

Muslimat, A. (2021). Masa Depan Kampus Merdeka \& Merdeka Belajar: Sebuah Bunga Rampai Dosen. Bintang Visitama Publisher.

Murtini, U. (2008). Pengaruh Kebijakan Manajemen Keuangan Terhadap Nilai Perusahaan. Jurnal Riset Akuntansi dan Keuangan.Vol. 4, No. 1, pp: 32-47.

Ni Putu Yuria Mendra (2016), "Pengaruh Rasio Keuangan Terhadap Price Earing Ratio Pada Perusahaan Manufaktur yang terdaftar di Bursa Efek Indonesia Tahun 2012-2014" Universitas Mahasaraswati Denpasar,

Noryani, Y. B. G., Sari, W. I., Rosini, I., Munadjat, B., Sunarsi, D., \& Mahnun Mas' adi, G. (2020). Did ISO 45001, ISO 22000, ISO 14001 and ISO 9001 Influence Financial Performance? Evidence from Indonesian Industries. PalArch's Journal of Archaeology of Egypt/Egyptology, 17(7), 6930-6950.

Nurjaya, N., Affandi, A., Ilham, D., Jasmani, J., \& Sunarsi, D. (2021). Pengaruh Kompetensi Sumber Daya Manusia Dan Kemampuan Pemanfaatan Teknologi Terhadap Kinerja Aparatur Desa Pada Kantor Kepala Desa Di Kabupaten Gunungkidul, Yogyakarta. JENIUS (Jurnal Ilmiah Manajemen Sumber Daya Manusia), 4(3), 332-346.

Nuryani, Y., \& Sunarsi, D. (2020). The Effect of Current Ratio and Debt to Equity Ratio on Deviding Growth. JASa Uurnal Akuntansi, Audit dan Sistem Informasi Akuntansi), 4(2), 304-312. 
Sari, W. I. (2019). Analisis pengaruh inflasi, suku bunga SBI, nilai tukar terhadap return LQ 45 dan dampaknya terhadap indeks harga saham gabungan (IHSG) di Bursa Efek Indonesia (BEI). Jurnal SEKURITAS (Saham, Ekonomi, Keuangan dan Investasi), 3(1), 65-75.

Sartono, (2013) "manajemen keuangan teori konsep \& aplikasi" Yogyakarta EKONISIA,2013
Sunaryo (2011) Pengaruh Current Ratio, Debt To Equity Ratio, Dan Devidend Pay Out Ratio Terhadap Price Earning Ratio Pada Kelompok Perusahaan Manufaktur Yang Terdaftar di Bursa Efek Indonesia Binus Business Review Vol. 2 No. 2 : 866-873

V. Wiratna Sujarweni (2014), "Metodologi Penelitian", Cetakan pertama, penerbit Pustaka Baru Press, Yogyakarta. 